\title{
O problema da cultura na Igreja Católica contemporânea
}

PAULA MONTERO

\begin{abstract}
A EXISTÊNCIA DE UM movimento mundial na direção do refortalecimento progressivo das crenças religiosas entre largos setores das populações urbanas que pareciam tender inexoravelmente para o secularismo, é hoje constatada por inúmeros estudiosos. Em contraposição à essa tendência, a Universidade (e certamente também a política), mantém fortemente arraigado seu ethos fundado em uma tradição laica. Ainda assim, cada vez é possível perceber com mais clareza a porosidade das fronteiras que procuravam manter as religiões longe da ciência e da política. Evidentemente, não se pode afirmar que o longo processo histórico que levou à independência das esferas do saber e da política com relação à religião tenha completado seu ciclo. No entanto, não há dúvida de que chegamos a um ponto de inflexão no qual essa ruptura começa a colocar mais problemas do que aqueles que somos capazes de resolver. As utopias novecentistas de liberdade humana, associadas ao progresso tecnológico, revelam hoje suas facetas mais perversas que vão das novas formas de autoritarismos à nova pobreza; ao lado disso, cresce o impacto das escolhas religiosas sobre a esfera da política.
\end{abstract}

Nesse contexto, no qual se percebe crescente expansão de toda sorte de credos, cabe à antropologia, mas também à sociologia e à ciência política, dedicar-se ao exame aprofundado da natureza dessa cultura religiosa. Como bem observa Maria Vitória Benevides, já foi possível perceber, em todo o Brasil, a extensão do impacto da adesão de identidades religiosas sobre eleições. Além disso, muitos estudiosos estão preocupados em mostrar como a formação religiosa tem modelado os mecanismos que levam a representação popular para a esfera da política. Minhas preocupações, neste trabalho, estão em afinidade com essa problemática mais geral que busca no campo da cultura parte das explicações para aquilo que se realiza no domínio da política.

Colocando no horizonte de minha reflexão esse encontro da cultura com a política, minha abordagem privilegia o primeiro termo tomando como pretexto o estudo das religiões. Não há como negar que no campo religioso se gesta, atualmente, grande parte dos Sujeitos políticos que passam a atuar na esfera pública buscando representar direitos. Torna-se mais do que necessário, portanto, procurar compreender o modo como esses Sujeitos são construídos e a visão de mundo que orienta a sua atuação pública. 
No caso da Igreja Católica, muitos trabalhos já demonstraram seu papel na formação de lideranças populares e sua contribuição na constituição do Partido dos Trabalhadores. Não é, pois, necessário retomar a questão desse ponto de vista. O que me parece interessante compreender neste momento, é o processo mais geral no qual o campo da cultura, ele mesmo, se tornou a arena onde as questões políticas entram em competição e as configurações culturais se tornaram instrumentos estratégicos na reivindicações de direitos. Minha primeira tarefa neste trabalho será, pois, a de traçar o panorama a partir do qual o tema da cultura se tornou uma questão nodal. Somente a partir desse quadro poderemos compreender como e por que ela constitui um problema-chave para pensadores e políticos e, ao mesmo tempo, para a Igreja.

\section{A cultura como problema}

Há muitas razões para que a cultura se tenha tornado um problema fundamental no mundo contemporâneo. Mas não há dúvida que a Segunda Grande Guerra foi um marco importante nesse processo. Isto porque o nazismo, particularmente sua eficácia na conquista da adesão popular, representou um grande trauma para a boa consciência européia. Adorno explicita bem esse sentimento quando se pergunta como um continente que alcançou o ápice da civilização, da elegância cultural, pode chegar a esse horror da morte planejada, calculada: como a própria civilização fora capaz de abrigar a barbárie?

Essa questão espicaça boa parte da consciência européia a qual, atribuindo-se auto-representação que a coloca do topo da civilização - a mais sofisticada que o mundo já conheceu - se vê diante do paradoxo de ter sido capaz de planejar o genocídio generalizado. E, o que é pior, com ampla adesão da vontade popular. Seria mais fácil reafirmar o vigor dos valores democráticos se o nazismo tivesse sido apenas perversão institucional, imposição de um Estado totalitário. Infelizmente, houve a irresistível adesão da população e de setores proletários a essa vontade de poder. Nesse contexto torna-se claro por que a questão da produção da consciência volta a ser colocada como problema teórico e político.

O marxismo parecia ter definitivamente equacionado a questão: tendo chegado à consciência, a classe levaria a História para seu destino irrevogável - o fim do Estado. Mas o nazismo foi a prova de que o destino da História não é tão claro quanto se poderia supor e que a consciência não basta para dar a ela um bom destino. Pensadores como Adorno e Horkheimer (1970) colocam-se, pois, a questão de como repensar o problema das ideologias e, percebendo a necessidade de ampliar o escopo da reflexão para além dos partidos políticos e do Estado, procuram pensar o lugar dos meios de comunicação na produção da consciência ideológica e da cultura do mundo contemporâneo. É, portanto, no contexto de um revigoramento do humanismo ilustrado do pós-guerra, que o problema da cultura vai se tornando chave para pensadores, políticos e governantes europeus. 
Entretanto, nesse primeiro momento a cultura ainda é basicamente pensada em termos de educação: é quase o seu equivalente. Supunha-se que a educação das consciências seria capaz de recuperar o humanismo inerente à cultura européia. Pela educação seria possível ensinar a tolerância, seria possível evitar um novo surto de totalitarismo. E, mais ainda, pela educação seria fatível superar o fosso que separava os países pobres dos países ricos, desigualdade esta percebida como a grande ameaça que poderia levar a uma nova conflagração e a uma nova ruptura cultural. Pode-se dizer, pois, que a educação foi a grande utopia do pós-guerra: foi pensada como a via real da solução dos grandes problemas da humanidade.

Há ainda outro elemento muito importante no panorama do pós-guerra que fez da cultura uma questão política: o processo de descolonização da África a partir dos anos 50. Por que esse processo interessa o tema que aqui nos ocupa? A descolonização teve como uma de suas principais consequiências a emergência repentina de novas nações no cenário mundial - nações com culturas não ocidentais - que começam a reivindicar voz e voto nas grandes decisões mundiais. Os novos Estados assim constituídos querem participar dos fóruns mundiais de decisão, e, para pressionar os países centrais, organizam suas forças em blocos culturais (Della Cava \& Montero, 1989).

O pós-guerra abre, pois, um período de reorganização das forças em escala planetária. Mas esse realinhamento vai muito além da divisão Leste/Oeste, da organização dos dois grandes blocos da Guerra Fria. Na verdade, o próprio Ocidente procura refazer suas alianças e inicia movimento de reagrupamento interno buscando garantir a cooperação econômica e cultural como caminho para uma paz mais duradoura. Com efeito, esses são os objetivos mais explícitos da Carta das Nações que funda a ONU, em 1945 - a cooperação econômica e cultural entre as nações. É preciso lembrar também que no mesmo ano foi fundada a FAO - organismo internacional voltado para o problema da fome no mundo. E que, no ano seguinte, 1946, funda-se a UNESCO, órgão especializado em proteger a liberdade humana e desenvolver a cultura. A partir desses elementos já é possível perceber o modo como o problema da cultura está posto nos fóruns de decisão mundiais. A desigualdade econômica desafia a cooperação e a paz - é preciso encontrar os mecanismos para que as diferenças convivam. Nesse sentido, uma das maiores preocupações da UNESCO nos anos 50 será o problema do racismo.

É neste contexto otimista, pautado na esperança do revigoramento do humanismo, da razão e do desenvolvimento humano que se dá a grande abertura da Igreja para o mundo moderno. Ela expressar-se-á no Concílio Vaticano II, realizado em Roma em 1960-1965. Muitos autores concordam em dizer que o Concílio Vaticano II foi o grande evento que fez com que a Igreja se reconciliasse com o mundo moderno e passasse a ter nele parte ativa. Nesse momento, em que a Igreja revê todas as suas posições doutrinárias sobre seu lugar no mundo, ela incorpora para si, e as faz suas, as grandes promessas da modernidade. 
Abandonando a interpretação transcendente do mundo, os teólogos começam a incorporar os instrumentos e conquistas das ciências, em particular as ciências sociais, ao seu pensamento. Além disso, também se reconcilia com a técnica e passa a defender avanços tecnológicos como caminho para o progresso mundial. Mais do que isso, o Concílio Vaticano II põe o homem - o homem concreto, histórico - no centro da sua reflexão.

\section{A Igreja se volta para o homem}

Tal deslocamento promove mudança radical no eixo da atuação da Igreja, que deixa de ocupar-se prioritariamente de Deus e dos seus desígnios, e se volta para o homem e seus problemas. Essa é uma das razões que nos permite compreender a rapidez com a qual padres e intelectuais ligados à Igreja incorporaram os instrumentos analíticos das ciências sociais: a formação em Antropologia, Sociologia e Ciência Política fornece os instrumentos de ciência necessários ao diagnóstico e solução dos problemas humanos. Pode-se afirmar que nesse movimento, que incorpora uma visão histórica do homem, se dá um deslocamento da noção de cultura tal como ela vinha sendo operacionalizada pelos organismos internacionais e pela própria Igreja. Neste momento, ela deixa de ser pensada como erudição ou educação, passando a prevalecer o ponto de vista antropológico de cultura: cultura como dimensão do homem; todo homem, por mais ignorante que pareça, por mais atrasado, é portador de uma cultura que é preciso conhecer e compreender.

Ainda que nesse particular a Igreja acompanhe o redirecionamento geral dos organismos europeus que, no contexto desenhado, fazia da cultura um dos instrumentos mais importantes da reconstrução da Europa por suas características institucionais mais específicas, ela é particularmente sensível ao problema da cultura. Por que?

Em primeiro lugar é preciso lembrar que grande parte dos religiosos não são mais de origem européia, mas, ao contrário, vem dos países do Terceiro Mundo. A América e a África são os grandes celeiros de vocações, enquanto declina numa Europa cada vez mais secularizada o recrutamento religioso. Em segundo lugar, as grandes religiões - aquelas que Max Weber chamou, com o cristianismo, de religiões universais - vicejam fora da Europa. Torna-se claro, portanto, porque, nesse contexto mundial, Roma precisa do Terceiro Mundo. Mas a guerra de descolonização alterou o contexto político dentro do qual essa aliança ganha sentido. Não se pode esquecer que a Igreja foi, desde a primeira hora, aliada dos governos europeus na sua missão colonizadora. Desse modo, não há como evitar que os países colonizados vejam a Igreja como cúmplice da colonização e o cristianismo europeu como instrumento de desenraizamento cultural típico do colonialismo. Assim, para manter-se dentro da órbita destes continentes onde está a grande parte do catolicismo, a Igreja precisou equacionar sua relação com 
as colônias. Para tanto, procurou refazer sua identidade institucional de modo a não mais ser identificada com o colonizador europeu. Nesse processo, a questão cultural se torna o nó górdio de sua atuação: a Igreja toma a consciência da necessidade de reinventar uma cultura cristã que não seja mais percebida como simples reprodução impositiva de uma matriz cultural de origem européia. Sob a pressão das Igrejas locais da periferia, viu-se obrigada a se deseuropeizar, de modo a libertar a instituição de mais de 500 anos de um trabalho missionário que a identificou com os interesses coloniais europeus.

Há ainda um terceiro elemento que é preciso ressaltar aqui: nesse processo de descolonização, os mais altos quadros eclesiais da Igreja não são mais apenas europeus; eles passam a ser recrutados também no Terceiro Mundo. Quando o Vaticano II se abre para deliberar a respeito do futuro da Igreja, a instituição toma consciência de que parte expressiva dos cardeais e bispos presentes não eram europeus. Assim, no momento em que a Igreja precisa tomar decisões que afetam seu lugar no mundo, a representação das nações periféricas tem ampla voz no equacionamento e na direção dessas resoluções.

\section{A diversidade cultural}

Ao compreender que o modelo do catolicismo não pode mais ancorar-se nos valores europeus a Igreja incorpora não apenas a cultura como reflexão, mas também a diversidade cultural como problema. Essa observação me parece particularmente importante. É tanto mais importante quando se percebe que no panorama das nações, as não-ocidentais começam a se organizar em grandes blocos culturais. Temos, a partir da Liga Árabe, em 1945, um movimento contínuo do Terceiro Mundo, que começa a definir sua própria cultura em termos independentes da cultura ocidental cristã e a pensar sua especificidade (e seu lugar) no mundo ocidental do pós-guerra e pós-colonialismo. Nesse contexto, é mais do que premente para a Igreja repensar o que sempre chamou de missão, isto é, lançar-se pelo mundo na tarefa de conversão dos outros. O fim das relações coloniais obriga a Igreja a redefinir as relações entre o centro romano e as igrejas locais. Tal movimento foi, na verdade, bastante rápido. Menos de 50 anos antes, em 1919, a Igreja católica ainda dividia o mundo entre cristãos e pagãos. As relações entre centro e periferia eram equacionadas de modo muito simples. Os pagãos deveriam ser convertidos, cristianizados ou mortos.

Cinqüenta anos depois, essa divisão tão sumária não é mais aceitável. A emergência de nações não-ocidentais onde o cristianismo já se implantara, a perda de hegemonia religiosa em países tradicionalmente cristãos, a reabertura diplomática para o Leste, profundamente religioso, são alguns dos fatores que tornam inoperante, nos anos 60 , a noção de paganismo. Fala-se agora em diálogo como uma das finalidades mais fundamentais da missão. Assim, ao invés de definir os outros como pagãos, o trabalho missionário começa a reconhecer que os 
indivíduos podem, legitimamente, escolher outras crenças religiosas; este novo outros passa a ser chamado de não-cristãos, eufemismo interessante que denota o enfraquecimento dos objetivos de conversão, antes orientadores do trabalho missionário (Montero, 1995).

Não é sem importância o fato de que esse também é o momento no qual os papas começam deixar a sede do Vaticano com mais freqüência. Paulo VI vai para o Oriente, para a Ásia, visita a África. Roma deixa de ser o centro da cristandade. É preciso costurar este mundo cristão com a peregrinação papal que refaz no tempo e no espaço a unidade de um reino que na história se fragmenta em pequenas autonomias étnicas. João Paulo II foi mestre no uso simbólico dessas viagens pelos continentes. Ele soube fazer da peregrinação o modo de atuar mais eficiente da Igreja contemporânea. Sem dúvida alguma, João Paulo II foi o papa que mais viajou na história recente do Vaticano (Montero, 1992).

No momento em que Roma procura relativizar o centro do poder institucional da Igreja, estimulando a autonomia das igrejas locais, torna-se necessário forjar, em novos termos, as relações entre doutrina oficial e crenças locais que antes se associavam no sistema da conversão. A Igreja procura, pois, os termos a partir dos quais vai definir sua relação com a diversidade cultural. Na verdade, dos anos 50 para cá, experimenta vários. No início falava em adaptação da Igreja romana aos países não-europeus. Em seguida, considerando essa noção ainda muito etnocêntrica e eurocentrada, apropria-se da noção antropológica de aculturação. Também esse conceito foi criticado, a partir do declínio que essa noção sofreu no próprio campo da Antropologia, por ter como critério ou medida da aculturação os valores ocidentais. Hoje, fala-se em inculturação. Tal dificuldade em encontrar o termo adequado para expressar as relações entre culturas indica que a natureza, ela mesma, dessas relações é controvertida. A escolha entre um ou outro termo não é inocente. Cada um deles denota sutilmente uma maneira específica de definir as relações entre centro e periferia, da qual depende a geopolítica vaticana. Hoje em dia, como dissemos, a noção que prevalece é a de inculturação. Vejamos pois, quais os pressupostos implícitos nesses conceitos e suas conseqüências para a prática missionária.

A inculturação é uma noção que se formula em contraposição com o conceito de adaptação, o qual supõe ajustamento das especificidades culturais nativas aos valores europeus. Ao invés de trazer o nativo para o ocidente cristão, a inculturação pretende, ao contrário, fazer o movimento inverso: levar o missionário em direção à lógica da cultura tradicional. Alguns setores da Igreja chamam esse movimento de indianização ou africanização da doutrina e prática cristãs. Nesse sentido, ela abandona a vontade de conversão do outro e assume a posição antropológica clássica na qual o eixo da relação entre duas culturas diversas é a compreensão e o conhecimento. As conseqüências dessa nova postura diante do outro já começam a se tornar visíveis. Em particular, tornam cristalino 
e crítico um dos principais dilemas do trabalho missionário que antes se resolvia pela anulação da alteridade pelo conceito de paganismo: a contradição entre tornar-se outro (indianizar-se, africanizar-se) e manter a universalidade do catolicismo. Essa contradição que, evidentemente, não pode ser resolvida com simplicidade, está posta hoje, na atuação pastoral e missionária da Igreja.

Até o momento descrevi o cenário. Vejamos agora o ator. O personagem principal do drama que encena o conflito entre a universalidade da fé e a particularidade das culturas é o Papa João Paulo II, eleito em 1978 e grande intérprete de uma Igreja que se quer ao mesmo tempo universal e nativa.

\section{O significado \\ de um Papa polonês}

Não é pouco significativo que se tenha eleito um papa polonês. Temos, pela primeira vez na história da Igreja, um pontífice oriundo de um país periférico da Europa. Sua origem polonesa não é fato acidental, nem secundário. A Polônia é um país que ostenta profunda tradição cristã, mas, ao mesmo tempo, situava-se, na geopolítica mundial, no sistema de alianças do bloco comunista. Era um país do lado de lá. Paradoxalmente, é justamente essa sua posição no sistema político mundial que torna a ênfase na cultura um dos instrumentos políticos mais importantes da diplomacia vaticana - a cultura se torna a grande questão desse pontificado. Logo depois de eleito, João Paulo II cria imediatamente o Conselho Pontifício para a Cultura, objetivando fazer dele tribuna e canal para o desenvolvimento de sua atuação nesse campo.

Mas por que o fato de o Papa ser polonês foi tão importante? Para responder satisfatoriamente a essa questão, que tem implicações muito vastas, seria preciso retomar a história recente da geopolítica vaticana, o que nos levaria muito longe. Limito-me, pois, a resumir e ressaltar alguns elementos que têm relação imediata com nosso tema da cultura. O fato deste Papa vir de um país então comunista ou, na versão pontifícia, de um país cristão que foi usurpado pelo comunismo, faz com que Roma desenvolva três estratégias fundamentais, nãoexplicitadas, mas que estão presentes desde o início do seu mandato: a primeira é evidente, contribuir para o fim do comunismo; a segunda é restaurar a Igreja na Polônia, conquistar dos governantes a promessa de que ela será novamente oficializada; e a terceira, mais abrangente, é integrar a Polônia (e o Leste) à Europa, refazendo uma grande Europa, que vá do Mediterrâneo aos Urais. Era o grande projeto político do Papa, a ambição que acalentava. Não há dúvida que ele era também a pessoa mais indicada para realizá-la. Por que isso me parece tão evidente? A resposta pode parecer simplória: por ser de nacionalidade polonesa. Como este fato, aparentemente banal, pode ser elevado à categoria de elemento de explicação? 
Por ser, ao mesmo tempo, polonês e Papa, João Paulo II era capaz de se apresentar à Europa - e ao mundo - como mediador político universal. Estava melhor posicionado que os Estados nacionais para tentar superar a barreira que separava a Europa do Leste da Europa Ocidental. Karol Wojtyla podia facilmente apresentar-se como estando acima da política. A Igreja não é um Estado, ou pelo menos não um Estado como os outros. Não é inverossímil portanto que ela pretenda estar acima dos interesses próprios da política. O Papa não reivindica direitos e privilégios nacionais. É claro que sua atuação também é política, mas não no sentido mais específico de política partidária ou de governo. Assim, ele tem legitimidade para se apresentar como porta-voz de uma instituição que é universal e que está presente em qualquer cultura - na África, na Ásia etc. Por falar em nome de todas as culturas, João Paulo II critica o particularismo (e o egoísmo) das nações em defesa de um humanismo que se quer universal. E mais ainda. Por estar presente em quase todas as culturas humanas a Igreja se vê como uma instituição capaz de superar a grande ameaça que ronda o mundo contemporâneo: a fragmentação. Com isso quero ressaltar que o fato de a Igreja ser, concretamente, uma das poucas instituições, senão a única, presente em todos os continentes, lhe garante unidade, mantendo suas partes organicamente solidárias; isto a torna uma instituição particularmente apta, portanto, a costurar com seu sistema a diversidade cultural. Diferentemente dos Estados que são movidos por interesses de fronteira, de conflitos de mercado, por disputas de soberania etc., a Igreja situa-se além dos projetos nacionais.

\section{A crise do Estado-nação}

A fragilidade dos Estados nacionais se torna particularmente visível na década de 80. Isso porque, nessa década, os problemas mundiais - a questão ecológica, os capitais transnacionais, a comunicação em redes etc. - vão delineando, de maneira cada vez mais evidente, o cansaço da idéia de nação. Autores como Benedict Anderson, entre outros, têm mostrado como essa idéia - que supõe a coincidência entre uma língua, um território e um Estado - foi forjada no século XIX no contexto dos processos de unificação nacional e ligada à idéia de soberania (Anderson, 1989). Ora, na conjuntura contemporânea em que a Europa se encontra à procura de uma identidade continental, identidade colocada acima das soberanias nacionais, mas apoiada em realidades locais, essa Europa precisa superar os Estados nacionais.

Nesse processo de construção da unidade européia João Paulo II teve um papel cuja relevância não se pode escamotear. Pode-se afirmar que ele teve sucesso integral no front Leste. Foi um dos personagens centrais na derrota do comunismo na Polônia, fez a ponte que desde os anos 60 a Igreja procurava restabelecer com o Leste europeu. E mais do que isso. Colocou um país periférico da Europa - a Polônia - no centro do mundo cristão. É verdade que desde os anos 60 as iniciativas do Vaticano conseguiram estabelecer alguns laços diplomáticos com o 
mundo comunista. Estabeleceram-se relações com a Iugoslávia, com Cuba, com a Alemanha Ocidental.

Mas com João Paulo II tal aproximação mudou completamente de natureza. Tornou-se mais íntima, mais sólida, posto que ele é um papa polonês: tendo vindo do lado de lá, conhecia de perto a experiência comunista e havia lutado contra ela. Chegou, pois, ao posto mais elevado da hierarquia religiosa levando na bagagem o papel-chave que desenvolveu no Sindicato Solidariedade em aliança com o Primaz da Polônia. O que seria importante destacar na ação que eles desenvolveram contra o governo comunista? $\mathrm{O}$ mais significativo parece ser a estratégia adotada pelo Sindicato, que não desenvolvia uma estratégia de ação fundada em uma linguagem diretamente política: não reivindicava por exemplo, a derrubada do Estado comunista pela ação popular. Segundo a versão do próprio João Paulo II, o Sindicato pretendia atuar apenas no plano da cultura, ou seja, sem enfrentar diretamente o sistema militar comunista.

Por outro lado, o Papa era um eslavo entre os eslavos, portanto, um interlocutor privilegiado da Europa do Leste e da União Soviética. Isto pode ser demonstrado a partir de muitas evidências: em 1978, ele encontra-se com o Ministro de Relações Estrangeiras da União Soviética e, em troca da não-invasão da Polônia, promete moderar o ardor grevista dos poloneses. Faz, pois, uma aliança com a União Soviética, na qual, em troca da preservação da Polônia, interfere na política do Solidariedade. Em 1980, faz novo acordo com o governo soviético: pede que o governo reconheça o Sindicato e, como contrapartida, dá garantias de que a ação sindical não entrará no campo político-ideológico. Em 1981, João Paulo II coloca o peso do Banco Ambrosiano no suporte das ações do Sindicato. Muito dinheiro entrou na Polônia via banco do Vaticano. Talvez essa conjuntura faça parte da constelação de pressões econômicas e políticas que levou o banco à falência. Em 1990, o Papa é o único líder europeu a encontrar-se com Gorbachev. Sua nacionalidade polonesa também parece ter sido importante no feito diplomático.

Todos esses êxitos do Vaticano em sua política de abertura para o Leste nos permitem perguntar: que lições teria o Papa tirado de sua experiência polonesa? Acho que a principal delas, e a que mais nos interessa aqui, pode ser resumida na constatação de que a cultura se tornou a nova arena onde se enfrentam as forças políticas presentes no mundo contemporâneo.

\section{A renovada importância da cultura}

O modo como o Vaticano investiu no campo da cultura é bom exemplo do fato, hoje evidente, de que política não se faz mais apenas no campo propriamente político. Grande parte das disputas deslocou-se para o jogo das significações e identidades ou, pelo menos, esta se tornou a linguagem necessária através 
da qual se dizem hoje os conflitos de poder e os interesses. Quais conclusões podemos tirar dessa constatação? A principal delas nos parece ser a importância renovada da Igreja - uma instituição que parecia destinada ao declínio, que parecia completamente desencaixada no mundo secular europeu, passa a ter lugar central no debate e nas articulações propostas em torno das novas questões européias contemporâneas. A Igreja ganha nova importância como instituição mas também como cultura, forma específica de visão de mundo que propõe uma formulação para os problemas contemporâneos. Essa compreensão profunda da configuração do mundo moderno e de seus dilemas expressa-se nas falas de João Paulo II quando diz que "a religião se torna a alma da cultura. E que não há cultura viva, não há nação viva, sem cultura religiosa".

A segunda constatação diz respeito ao fato de que, quando a cultura se torna o espaço no qual se configuram as forças políticas em disputa, as crenças religiosas se tornam sinônimo de identidade. Ora, sabemos que a reivindicação de identidade é um dos caminhos através dos quais se formam e se conformam os grupos em luta nas arenas nacionais e internacionais. A defesa da identidade é a linguagem utilizada na expressão de interesses e reivindicações. Vale a pena enfatizar esta idéia, pois ela me parece importante: quando falamos em política no sentido mais vasto, ou quando pensamos na luta política que se trava para além dos partidos, é preciso voltar nossa atenção para o modo como os grupos se constituem e passam a existir na esfera pública. Como se dá atualmente, a emergência de grupos políticos? Como já exposto, a produção de identidades é um dos caminhos mais eficazes para a constituição de grupos em disputa no mundo de hoje. A produção dessa identidade e o esforço de mobilização que seu reconhecimento público exige, nos revela que o processo simbólico de invenção ou reinvenção das características culturais de um grupo tornou-se um dos mais importantes instrumentos da disputa política e da garantia de preservação de interesses. Assim, se é verdade que a identidade é o caminho através do qual se expressam interesses e reivindicações, a cultura se torna um dos recortes privilegiados para a compreensão da luta política - seu sentido, seus objetivos e seus agentes.

O terceiro elemento importante que seria preciso ressaltar é o seguinte: a religião torna-se cada vez mais instrumento, linguagem e fundamento legitimador de processo de produção de autoridade nas sociedades contemporâneas. Chamo aqui autoridade, o poder de convencimento outorgado a uma instituição ou pessoa considerada legítima. Ter autoridade para falar é ser reconhecido como autorizado a falar. A religião, ao construir identidades, ao mesmo tempo produz a autoridade da fala. É a autoridade para dizer que confere a João Paulo II o poder de outorgar-se legitimamente a autoridade de interlocutor das culturas, justamente no momento em que se estabelecem e se constróem os blocos de poder no mundo. Assim, se estes blocos são recortados economicamente, o processo simbólico de produção de uma identidade cristã suprime a fragmentação 
repondo a unidade no âmbito da cultura. Temos, pois, que em um mundo que tende para a fragmentação, a Igreja é uma força que costura as diferenças. Este não é um movimento de pouca importância.

Pode-se dizer que foi o êxito polonês que permitiu ao papado consolidar essa imagem de unidade cristã superando fronteiras políticas, econômicas e culturais, como paradigma a ser reatualizado em outros cenários. O sucesso de sua política polonesa lhe permitiu construir um modo de entender os problemas contemporâneos e de atuar que seria progressivamente operacionalizado em outros contextos: na Europa do Oeste, tomando como pretexto o processo de unificação europeu; e na América, por ocasião das celebrações dos 500 anos do descobrimento que dizem respeito ao processo de incorporação da América no bloco de poder ocidental e levam à tentativa de estimular a emergência de uma identidade latino-americana. Podemos, desde já, adiantar que a Igreja alcança relativo sucesso no primeiro caso e sofre fracasso relativo no segundo. Seria interessante nos perguntarmos as razões que estão por detrás de resultados tão díspares: por que a movimentação relativa à unificação da Europa, à construção de uma identidade cristã européia alcança êxito relativo enquanto a tentativa romana de construir uma unificação identidária cristã para a América sofre oposição pertinaz e sistemática das igrejas latino-americanas?

A questão talvez seja ampla demais para que possa ser respondida aqui de modo minimamente satisfatório. De qualquer modo, posso adiantar alguns elementos que, se não garantem uma demonstração cabal do fato, pelo menos situam a origem desta intuição. Vamos nos deter, sobretudo, na operacionalização do paradigma polonês no discurso de reunificação da Europa e deixar para outra ocasião a análise do modo como ele foi aplicado na América.

Uma das principais questões que é preciso colocar quando se procura compreender o sentido de se reivindicar, hoje, uma identidade cristã para a Europa diz respeito ao papel de João Paulo II no processo de unificação do continente. Não há como negar que sua atuação foi chave. É claro que esse processo é muito mais abrangente e anterior à emergência deste papa no cenário mundial na década de 80: o processo de reconstrução de Europa recua pelo menos até a Segunda Guerra. No pós-guerra a ideologia da nacionalidade começa aos poucos a revelar suas fragilidades. Muitos autores já ressaltaram o fato de que a partir de então, começam a se tornar evidentes as contradições inerentes à noção de Estadonação. Isto porque a mônade Estado-nação pressupunha a defesa de uma economia nacional aliada à defesa da soberania territorial e política. Entretanto, no contexto econômico e político do pós-guerra a colaboração entre os Estados se torna fundamental: o desgaste da guerra exigiu um esforço comum de recuperação econômica que ultrapassava as fronteiras nacionais e fragilizava a operacionalidade da noção de soberania. 


\section{A federalização da Europa}

O Plano Marshall, que representou o primeiro passo na direção de uma política econômica continental, desencadeou complicado processo de federalização da Europa. Esse processo de unificação do continente - ue se dá em um primeiro momento em nível econômico - começa, em seguida, a criar instâncias supranacionais de decisão e reivindicação. A década de 80 vê o movimento alcançar a esfera da cultura e, paradoxalmente, é nessa instância que o problema da unificação se torna mais espinhoso. É fácil promover a unidade econômica; a política depende de um esforço de concertação maior, mas é complicadíssimo tentar promover a unidade cultural. Talvez por isso, apesar do grande desenvolvimento econômico que o mercado comum trouxe à Europa no final da década de 80 , ela ainda está às voltas com o problema de sua identidade cultural. Em um importante Simpósio Internacional realizado em Paris, em 1988, a Europa, tendo como horizonte a unificação do continente em 1992, se perguntava: quem somos? Há uma identidade européia? É interessante o modo como neste encontro, que reuniu mais de 100 intelectuais, jornalistas e pesquisadores, são abordados os aspectos culturais dessa construção. Os europeus se perguntam: o que faz da Europa a Europa? O que a faz explodir ou fragmentar-se? Quais os elementos culturais que são capazes de federalizar o continente? Qual o papel dos intelectuais? Qual o patrimônio cultural existente? Quais os critérios para decidir o que é ser um país europeu?

Em meio a tantas dúvidas a Igreja acena com algumas certezas. Para cada uma destas questões o Papa Wojtyla aponta em direção a uma resposta. Não se trata aqui de tomarmos partido e decidir se estamos de acordo, ou não, com suas proposições. $\mathrm{O}$ que nos parece interessante é observar o modo como ele responde a esse tipo de problema. Quero dizer com isso que as análises que se contentam em qualificar como conservador ou tradicionalista este pontificado, não serão capazes de compreender o modo específico como ele responde à indagação da identidade européia. Gostaria de demonstrar aqui que a Igreja (pelo menos no contexto europeu) está em profunda sintonia com as questões do seu tempo. Ela reproduz o mesmo movimento que as forças sociais realizam no sentido da reinvenção da tradição. Porque ela se viu face aos mesmos dilemas com os quais o mundo europeu se defrontou em função da crise da soberania das nações. A Igreja, pela reinvenção de uma identidade cristã para a Europa, procura enfrentar o nó central das questões que, no meu entender, caracterizam o mundo contemporâneo. Vejamos se é possível delimitar melhor essa asserção.

Não é mais novidade afirmar que o mundo tende vertiginosamente para a mundialização da cultura via mercado. No entanto, não me parece que se esteja dando a necessária atenção à contraface necessária desse processo de mundialização, que é a tendência para o reforço radical das culturas locais e étnicas. Vivemos em um mundo cujo movimento vai ao mesmo tempo no sentido 
da mundialização via mercado e no sentido da afirmação radical das identidades locais. No centro dessas tensões contrárias o Estado-nação experimenta seus momentos de crise. Como conseqüência, o mundo da política parece não ter mais lugar próprio, posto que desaparecem as instâncias mediadoras entre o universal e o particular, papel até então delegado ao Estado nacional. Perdem sua função tradicional as instâncias mediadoras entre o mercado mundial, que reduz valores, projetos e coisas à circulação de riquezas - o capital -, e as pequenas identidades étnicas voltadas para si mesmas até o ponto da intolerância radical entre elas. Portanto, desaparece o espaço crítico tradicional que se fragmenta em pequenas autonomias; e nesse movimento o campo da democracia se degrada.

Embora sem colocar a questão exatamente em tais termos, me parece que este Pontificado, na sua preocupação com a cultura, vai na direção de procurar enfrentar o problema. Vejamos pois como Roma faz este movimento, ou, dito de outro modo, que tipo de imaginário constrói para dar conta do dilema. Enfatizo nessa colocação um tipo de procedimento, um modo particular de abordar a análise desse Pontificado. Pretendo analisar a construção imaginária que ele realiza no momento em que enfrenta o dilema da perda de mediadores entre o particular e o universal. $\mathrm{O}$ arranjo imaginário com o qual procura posicionar a Igreja na linha de frente dos acontecimentos, propõe um projeto evangélico capaz de envolver em um sistema único, as práticas político-religiosas dos quadros espalhados pelo mundo e inseridos nas mais diversas culturas.

\section{O Vaticano e o problema da cultura}

Para resumir rapidamente as características desse processo, diria que três elementos chamam nossa atenção quando analisamos os documentos oficiais e os discursos do Papa sobre o problema da cultura. Três elementos que de certa maneira procuram articular a dimensão universal da Igreja à dimensão local da cultura. Quais são eles?

Em primeiro lugar, é possível perceber que, de maneira recorrente, a Polônia é metáfora de uma identidade supranacional cristã. Em seguida observa-se que a cultura, e não o Estado e nem as fronteiras territoriais, é vista como o elemento fundamental formador e constitutivo da nação. Finalmente, percebe-se que a História é relatada enquanto narrativa mítica, e se transforma em elemento fundamental da construção de identidades. A História é utilizada na forma do mito... Vejamos se é possível detalhar com maior precisão esses três elementos.

A Polônia como metáfora. A Polônia é fundamental na construção mítica que organiza o discurso pontifício porque o Papa, como enfatizamos, é polonês e porque, como vimos, obteve resultado expressivo em sua tentativa de integrar cultural e politicamente a Polônia à Europa. Em seus discursos, a história da nação polonesa funciona, pois, como metáfora discursiva: quando o Papa diz 
"eu sou filho da Polônia", e o diz de maneira recorrente quando se dirige aos europeus, essa imagem faz parte de uma construção em processo, que eu chamaria de mítica, e tem como base, como núcleo central, a visão de uma Europa unificada, supranacional e cristã. Essa visão articula uma identidade nacional que está distante do Estado - até mesmo se contrapõe ao Estado - e próxima da tradição. Isso significa que a nação polonesa não coincide nem com o Estado polonês nem, tampouco, com o território polonês. A nação polonesa constitui uma cultura e, é claro, uma cultura cristã, o que nos leva ao segundo elemento.

É possível perceber como a imagem da nação polonesa, evocada continuamente pelo Papa, separa os elementos que, na construção histórica dos nacionalismos, foram progressivamente considerados como equivalentes: o Estado, o território e a cultura. O último termo passa a ser considerado mais decisivo para a identidade da nação do que o traçado das fronteiras territoriais e políticas. No caso da nação polonesa, essa ruptura foi característica de sua turbulenta história nacional. A permanência do sentimento nacional polonês para além das sucessivas perdas territoriais da nação se torna uma demonstração histórica de que a nação não depende do território. O Papa rememora pois essa história polonesa: a Polônia perdeu a sua independência por mais de cem anos. Em 1772, foi dividida pela Áustria, pela Rússia e pela Prússia. Em 1793, foi dividida pelos russos; em 1795, outro levante fracassa e os russos fazem nova partilha, na qual a Polônia desaparece do mapa. E, no entanto, lembra João Paulo II, mesmo tendo desaparecido da geografia ela existe e permanece como Polônia. Essa permanência é finalmente reconhecida pelo Tratado de Versalhes (1919) que reinscreve a Polônia no mapa europeu. Mas a história trágica dessa nação não encontra ainda seu repouso. Como sabemos, na Segunda Guerra a Polônia é novamente invadida e ocupada pela URSS. A ocupação comunista carrega, portanto, o estigma e a memória de uma sucessão de invasões anteriores perpetradas contra a nação. Torna-se, pois, mais fácil compreender porque vencer o comunismo passou a significar, nesse contexto, a única possibilidade de restauração da integridade da vida nacional.

Essa história traumática é aquela que o Papa rememora continuamente para dizer que mesmo tendo perdido tantas vezes sua independência, a Polônia continua sendo ela mesma. Nessa argumentação, a cultura se torna mais decisiva do que o território e as fronteiras políticas para definir a existência e os limites da nação, e ela se afirma justamente na sua contraposição e até mesmo recusa do papel opressor do Estado.

Com efeito, o Estado é o inimigo a combater. Em um contexto político autoritário o Estado polonês está, naquele momento, totalmente identificado com a potência inimiga invasora: o Estado da URSs. Por isso, para resgatar a Polônia como nação, o Papa propõe a destruição do Estado. Nesse caso, o Estado não representa a soberania nacional, ele está estruturalmente incapaz de expressar a identidade nacional - é percebido como pura opressão. A cultura nacional 
deve, pois, resistir ao Estado. Mas, o que seria finalmente essa cultura, de que modo e em que instituições seria capaz de expressar a alma polonesa? Chegamos pois, ao terceiro elemento que aqui nos interessa.

No processo imaginário e discursivo de reconstrução da identidade cultural da nação polonesa, o Papa recorre constantemente à memória histórica. Ele faz, na verdade, da História, um instrumento ideológico-chave da construção de identidade: ela dará verossimilhança à sua narrativa sobre a fundação da nação. $\mathrm{O}$ interessante é que a identidade nacional, assim construída, é caracteristicamente étnica e não identidade soberana como aquela produzida como o equivalente civil do Estado. Nesse sentido, é a tradição cultural (e não política) que será importante na construção da alma nacional. Quais os recursos retóricos, que imagens estão na base dessa construção? Um rápido exemplo pode ilustrar, de imediato, o modo como a História se torna testemunha ocular da nação. Quando o Papa diz, "a História é testemunha de que a Polônia sempre foi um país de homens corajosos", e passa em seguida a enumerar todas as batalhas que os poloneses tiveram desde o século IX até o século XX, seu relato histórico constrói a memória de um povo que resiste. A memória da Polônia resistente é a chave para entendermos o modo como o Papa vê sua missão no mundo. A Polônia é menos um país do que uma comunidade moral. A Polônia é uma idéia. O mito do sofrimento histórico do povo polonês evoca o mito do calvário de Cristo.

$\mathrm{O}$ relato histórico, portanto, se faz sempre à maneira do mito. Mas o modo como João Paulo II evoca o passado da Polônia para recriar a unidade continental não é simplesmente a expressão idiossincrática de um modo ideológico de ver a História. Na verdade, esse é o modo particular como a História está presente no processo contemporâneo de construção das identidades. E isso me parece importante ressaltar. É por meio dessa evocação que o discurso faz do disperso, do fragmento, do diverso, uma essência. É claro que não basta apenas construir essa representação, é preciso ainda que ela seja verossímil, que apele para a experiência do homem na sua vida concreta. A capacidade de verossimilhança de um relato dessa natureza é sempre uma questão em aberto, posto que não está dada de antemão. Mas no caso polonês, é possível afirmar que a sociedade polonesa se reconhece nos relatos pontifícios. Há verossimilhança nesse mito histórico, nessa construção imaginária que o Papa sistematiza e divulga. No caso da Europa talvez seja mais complicado uma avaliação tão positiva. Há muitos críticos dessa construção discursiva do Pontificado, que busca nas culturas européias sua alma cristã. No entanto, é certo que a Comunidade Continental Européia se concretizou e a Igreja teve nela papel importante; mais do que isso, foi parte integrante dessa construção.

Na História mítica que o Vaticano elabora a respeito da unidade européia, a narrativa procura penetrar na experiência concreta do homem europeu. Se, ao rememorar a história da Polônia, Wojtyla evoca a imagem - experimentada 
historicamente por inúmeras gerações de combatentes - da Polônia resistente, a Europa do Papa é a Europa dos santos nacionais. Com efeito, ele vai de país em país escolhendo e canonizando santos retirados das tradições locais. Como que para compensar a fragmentação devocional que acompanha esse revigoramento da piedade regional, o Papa reafirma a universalidade da Igreja projetando-a em um espaço unificado: a Europa dos santos reunifica a geografia européia pelos caminhos da peregrinação. Nada mais secular na história da Igreja do que a romaria: em sua luta contra o paganismo ela representava um modo de reduzir as diferenças e de fazer confluir, sob a autoridade do rei e dos bispos, a sedimentação cultural das camadas populares (Sanchis, 1983:67). Por isso mesmo, nada mais contemporâneo na atuação da Igreja do que a peregrinação. Peregrinar é deambular, andar. Reconstruir no espaço geográfico a mesma unidade que se constrói no tempo mítico pela História. A peregrinação atravessa fronteiras, fala várias línguas. Vive a experiência de uma comunidade efetiva. Os santuários estão saturados de camadas arqueológicas de história: os romeiros investem nesses lugares as suas utopias. É por isso que o Papa anda e faz o povo andar. Na grande peregrinação a Santiago de Compostela, por exemplo, os jovens da Europa inteira caminham até a Espanha. Ao caminhar pela geografia dos santuários o Papa realiza no espaço e na experiência concreta a mesma unidade mítica que ele havia construído no tempo pelo seu uso da História. Nesse movimento coletivo dos fiéis ele retira as pessoas de seu enraizamento local, desloca-as de seu espaço social habitual, permitindo-lhes viver uma experiência, impalpável nos dias comuns, de uma fraternidade supracultural.

\section{O Papa e a América}

Dissemos anteriormente que o paradigma polonês foi aplicado à Europa; mas também o foi à América. Neste caso, porém, a operacionalidade do modelo encontrou maior resistência. Por diversas razões que não é possível retomar aqui, a identidade americana não foi sensível ao modelo polonês (Montero, 1995). A inadequação do modelo às particularidades da história americana se tornou evidente na tentativa romana de celebrar com pompa o descobrimento da América em 1992. É interessante notar que 1992 foi o ano da unidade européia e 1492 o ano do descobrimento da América. Ora, a América é um continente absolutamente estratégico para o Vaticano, uma vez que nele está grande parte da população católica do mundo. Razão já suficiente para que o Vaticano se preocupe em incorporar o continente a essa comunidade imaginária - no sentido de Benedict Anderson - cristã que ele está procurando detalhar, desenhar. Também aqui a História como um mito tem papel exemplar. Em primeiro lugar, porque estamos diante de um fato histórico: a Europa chega à América e faz desse acontecimento um ato fundador. No entanto, há cada vez menos consenso com relação ao sentido desse fato: até hoje não houve acordo sobre o que aconteceu em 1492. Para alguns, foi o ato heróico de um navegador; para outros, o início de uma trágica conquista. 
No contexto desse debate ideológico a História como disciplina é chamada a se tornar um instrumento de aferição da verdade sobre 1492. Assim, realizam-se seminários e congressos, ouvem-se os historiadores, escrevem-se livros. A História é chamada a ser o juiz dos atores em disputa pelo sentido do descobrimento da América. Nunca se fez tanta história sobre a América como nos últimos dez anos e nunca a verdade apareceu tão fora do alcance da História. Com efeito, os historiadores, ao serem instituídos como juízes da verdade do descobrimento, ou da verdade da conquista, foram pegos pela lógica desse jogo que os tornou atores ou instrumento da construção dessa identidade específica que é a identidade latino-americana. A História veio dar razão e consistência ao mito da América mestiça. Para os pensadores católicos latino-americanos, o catolicismo do continente não é uma incorporação direta da visão cristã européia. A América se quer diferente do catolicismo romano e reivindica raízes populares e étnicas que levariam à constituição de um catolicismo mestiço.

\section{As identidades dos latino-americanos}

Desde o século XIX os intelectuais estão se debatendo com o problema das identidades. O que parecia problema mais ou menos superado se repõe atualmente de maneira mais pungente do que nunca. Definir a cultura latino-americana é um problema para os intelectuais da Igreja, mas também para os leigos. Em outras palavras, o debate sobre o que somos não é um problema que interessa apenas aos intelectuais. Se pensarmos nas culturas indígenas, hoje, podemos nos perguntar: Quem é o índio no Brasil? Como eles mesmos recolocam para si a questão da identidade, base de seu movimento político? Não se pode esquecer que a partir dos anos 70, na América Latina, renovou-se como nunca o movimento de construção da identidade étnica, aquém dos Estados. Os mapuche se reorganizam, os negros reavivam sua memória africana. Pela América Latina se reinventam os índios e suas tradições.

A Igreja desempenha papel fundamental nesse movimento. Por tudo isso, parece ser preciso suspender o julgamento para não reduzir o trabalho da Igreja a uma intromissão detestável na cultura tradicional, mas tampouco louvar a tradição cristã como a alma da cultura. São construções cujo sentido maior nos cabe compreender. O problema é que somos parte integrante de tal construção, e essa é a nossa dificuldade. Nossa análise histórica e/ou antropológica é retomada pelos atores na construção de sua identidade. Autores como Octávio Paz, por exemplo, estão construindo identidades tão fictícias como qualquer outra. A identidade é necessariamente uma construção e do ponto de vista analítico não é possível decidir se a tradição é um peso ou é um avanço. O que me parece importante desvendar é como se processam esses elementos culturais, quem os processa e por que os processa, fazendo-o desse modo e não de outro qualquer. São essas as questões que a Antropologia contemporânea pode ajudar a resolver. 
Quando a questão está posta em termos de cultura, os instrumentos analíticos que tínhamos para decodificá-la não são mais tão eficientes. Não se pode deixar de observar que a esquerda da Igreja teve, até agora, imensa dificuldade de trabalhar no registro da cultura: nos anos 60-70 cunhou a noção de cultura popular, que no fundo visava a ser um instrumento de purificação da consciência popular eivada de superstições a serem banidas. Tratava-se então de criar uma cultura popular consciente, politizada. Com o enfraquecimento desse referencial político foi preciso revalorizar a cultura popular pelas suas qualidades intrínsecas, mas, na verdade, não se tem muita certeza quais são. Como caracterizar, pois, essa Igreja mestiça? Até onde posso ver a Igreja mestiça é uma construção ideológica monumental. Dela participam os intelectuais da Igreja, mas também literatos, historiadores, antropólogos... Os escritos de Leopoldo Zéa, Octávio Paz, e outros tantos autores latino-americanos, nos permitem perceber claramente que a noção de raça cósmica é uma construção de grande poder de evocação e mobilização. De certo modo, essa tentativa de construção de uma América mestiça foi também o projeto cultural no Brasil desde Gilberto Freyre. Assim, pode-se afirmar que, se há alguma especificidade latino-americana em contraposição aos universalismos europeus, essa universalidade é de natureza étnica e se constrói em torno da idéia de uma América mestiça.

No entanto, se a imagem é forte, as ações que suscita são freqüentemente contraditórias: no momento das disputas, essa América mestiça se desfaz em fragmentos. Parece-me interessante que os pensadores latino-americanos propunham para a América uma nova construção imaginária em oposição à construção imaginária que a Europa realizou sobre nós. Se analisarmos de perto as imagens através das quais Roma constrói a América cristã, poderemos perceber o quanto ela difere do retrato que os latino-americanos propõe para si mesmos. Há aí disputa de definições cujo sentido me parece interessante analisar. Mas não cabe nos alongarmos aqui nesta reflexão. Remeto, portanto, o leitor ao trabalho Entre o mito e a história. O V centenário do descobrimento da América, no qual desenvolvo este tema (Montero, 1995).

\section{Considerações finais}

Para concluir, gostaria de ressaltar, a partir das colocações feitas, a necessidade fundamental de se retirar a análise das instituições do referente estritamente político-ideológico que, de modo geral, orientou grande parte dos estudos sobre a Igreja; parece-me que a ênfase no político reduz a compreensão de sua atuação à simples constelação programática. Além disso, torna-se cada vez mais evidente que, tendo em vista esta constelação ser sempre conhecida de antemão, o pesquisador tende, de maneira quase inevitável, a levar a análise na direção de um exercício puramente classificatório que se ocupa em ordenar atores e comportamentos no interior de categorias como esquerda $\mathrm{x}$ direita, progressismo $\mathrm{x}$ conservadorismo, vencedores $\mathrm{x}$ vencidos e, no limite, bons x maus. É evidente o 
quanto tal procedimento enrijece a análise, impedindo-a de entender o que está em jogo nessa construção imaginária que a Igreja realiza sobre a cultura. Por outro lado, não se pode esquecer que a Antropologia é dona de vasta tradição teórica a respeito do estudo sobre as significações, cujo legado pode vir a constituir importante contribuição para a compreensão da dinâmica social do mundo contemporâneo. Parece-me que, mais do que nunca, o rito deve estar no centro de nossa reflexão. Através dele é possível desvendar com maior clareza a natureza dos jogos de interesses e de significações.

Toda vida social é constituída de celebrações que põem em operação um conjunto de ritos. A vida simbólica que os ritos põem em andamento não é, evidentemente, nem linear nem consciente. Nesse sentido pode-se dizer que todo mito, isto é, conjunto de representações que o rito atualiza, é sempre polimorfo e contraditório. Significa menos pelo que diz do que por aquilo que evoca. A noção de evocação me parece, pois, chave no equacionamento do problema da construção ideológica do mundo moderno. No meu entender é talvez mais importante compreender o trabalho de evocação que está contido nessas construções simbólicas, do que ater-se à construção ideológica explícita que enunciam. Hoje, torna-se evidente que os discursos ideológicos conscientes e ordenados dizem menos pelo seu conteúdo explícito do que pela sua habilidade em evocar.

Finalmente, diria que o mundo talvez precise daquilo que o Papa significa. Sua ênfase na cultura mostra que a Igreja tem consciência que, neste terreno, se jogam grande parte dos conflitos do nosso tempo. Sua defesa das tradições locais coloca a Igreja em consonância com as reivindicações étnicas do nosso tempo, no momento em que as culturas estão relativamente disponíveis para os mais diferentes reordenamentos de identidade. E, finalmente, o seu apelo ao senso ético é suficientemente universal para sensibilizar aos que se preocupam com a crise da razão que separa o conhecimento da ordem moral e do entendimento a respeito do devir humano.

Nota

1 Maria Vitória Benevides lembra o modo problemático como a questão das identidades e da defesa das culturas locais se liga ao debate a respeito dos Direitos Humanos. Como se sabe, esse foi o tema predominante na Conferência Mundial de Viena em 1994, que comemorou os 45 anos da Declaração Internacional dos Direitos Humanos. Segundo seu relato, predominou em todas as discussões a oposição cultura dos ricos/cultura dos pobres. Nesse contexto, a universalidade dos Direitos Humanos foi rigidamente contestada e resultou em posições tão radicais que impossibilitaram a redação de textos finais que contentassem a todos - ocidentais e orientais, desenvolvidos e subdesenvolvidos. A grande controvérsia situou-se em torno da tentativa de definir um direito universal que superasse a diversidade das culturas. Para muitos, a questão colocou-se como um dilema: entender os Direitos Humanos como históricos e, ao mesmo tempo, como naturais. 
Referências bibliográficas

ANDERSON, Benedict. Nação e consciência nacional. São Paulo, Ática, 1989.

DELLA CAVA, Ralph \& MONTERO, Paula. ...E o verbo se faz imagem. Igreja Católica e os meios de comunicação no Brasil: 1962-1989. Petrópolis, Vozes, 1989.

HORKHEIMER, Max \& ADORNO, Theodor. Dialética del iluminismo. Buenos Aires, Sur, 1970.

MONTERO, Paula. Tradição e modernidade: João Paulo II e o problema da cultura. Revista Brasileira de Ciências Sociais, ano 7, n. 20,7 out. 1982.

Entre o mito e a história. O V Centenário do descobrimento da América.

Petrópolis, Vozes, 1995.

SANCHIS, Pierre. Arraial: festa de um povo. As romarias portuguesas. Lisboa, Pub. Don Quixote, 1983.

Resumo

Neste artigo procura-se analisar o modo como a cultura se tornou um problema político e ideológico para a Igreja Católica, que tem diante de si a difícil tarefa de enviar sua mensagem cristã a todos os povos do mundo. Nele aborda-se o modo como esta instituição se propõe o papel de unificar as diversidades culturais e criar unidades imaginárias em meio às tendências antinômicas de mundialização das culturas e reivindicação de identidades culturais particulares.

\section{Abstract}

The aim of this article is to analyze in which ways culture became a political and ideological problem for the Catholic Church, in that it is faced with the hard task of projecting its Christian image to all the people of the world. It broaches the way this institution assumes the role of unifyng the cultural diversities and creating imaginary units among all the antinomic tendencies towards the globalization of cultures and the claiming of privative cultural identities.

Paula Montero é professora do Departamento de Antropologia da Faculdade de Filosofia, Letras e Ciências Humanas da USP.

Palestra feita pela autora no IEA-USP em 6 de outubro de 1994.

A autora agradece a Roberto Ventura e a Maria Victória Benevides a oportunidade de debate. Incluídos, à medida do possível, os resultados daquele encontro neste texto. 